\title{
Prevalence of oral Candidiasis and Risk Factors in Diabetic Pateints
}

\author{
Elham E. Moustafa ${ }^{* 1}$; Zeinab M. Kheiralla ${ }^{* 1}$, Soheir S. Maklad ${ }^{2}$, Sanaa M. Ashour ${ }^{1}$, \\ Mona A.Raoof ${ }^{2}$ \\ ${ }^{1}$ Botany Department Faculty of Women for Arts, Science and Education, Ain Shams University, Cairo, \\ Egypt \\ ${ }^{2}$ Microbiology and Internal medicine Departments, Faculty of Medicine for Girls Al-Azhar University, \\ Cairo, Egypt
}

Abstract:

Oral candidiasis has a strong association with diabetes. This study investigated the prevalence of candidiasis, effects of age and denture wearing on the isolation rate of Candida, virulence factors such as (germ tube (GT), gelatinase assay, phospholipase (PL) activities, biofilm (BF) formation) of different Candida species isolated from 40 confirmed diabetic patients with oral candidiasis and susceptibility of Candida isolates to antifungal agents. The prevalence of candidiasis was (67\%) which is more prevalent in middle age (40-60) years (65\%) and among females (65\%). Sixty Candida isolates were identified among which Candida albicans represented (53.3\%), followed by $C$. glabrata (31.7\%), C. tropicalis (10\%) and C. krusei (5\%). In denture wearers, the isolation rate of all Candida species was $94.7 \%$ while in non denture wearers was $53.7 \%$. The minimun inhibitory concentrations (MICs) of ketoconazle as the lowest concentration of antifungal that inhibited $100 \%$ of C. krusei while MIC for flucytosine that inhibited $90.6 \%$ and $84.2 \%$ of C. albicans and C. glabrata respectively, also the MIC for itraconazole and voriconazole that inhibited $93.5 \%$ and $81.2 \%$ of $C$. albicans. The MIC of amphotericin B was defined as the lowest drug concentration causing $100 \%$ inhibition of all Candida species. Candida albicans and C. tropicalis isolates were positive for all the virulence factors while $C$. glabrata and $C$. krusei were negative for GT, gelatinase and PL activities. $C$. krusei were positive only for BF formation. In Conclusion, Candida spp. in the oral cavity of diabetic patients are potentially pathogenic and can participate in infectious and inflammatory processes since they exhibit most of the virulence factors and resistance to most antifungals. Denture wearing, female sex and middle age are among the risk factors. Controlling serum glucose level and oral hygiene are essential in diabetics.

Keywords: Diabetes mellitus, Denture wearer, Candida spp., Antifungal susceptibility, Virulence Factors.

\section{Introduction}

Diabetes mellitus (DM) is a common disease worldwide. This disease has strong association with wide variety of infections (Wild et al., 2004). Candidiasis is the most common

\footnotetext{
* Corresponding author: elhamelasal@yahoo.com
} 
mycotic infection in the oral cavities (Abaci and Holiki-Uztan, 2011) and it has a strong association with diabetes (Manfredi et al., 2006). Several systemic or local contributing factors influence the balance between the host and yeast growth. The disturbance of this balance may result in transformation of the commensal Candida species to the pathogenic ones that lead to localized as well as disseminated infections (Janet et al., 2005). The high prevalence of opportunistic infections especially the oral candidiasis in diabetics had always remained of debate (Safia, 2010).

Diabetes mellitus is a metabolic disease characterized by hyperglycemia due to defects in insulin production and/or insulin action. Oral candidiasis has a significant association with the glycemic control and changes in salivary pH due to hyperglycemia (Kumar and Kannan, 2010). Numerous oral complications have been related to DM (Sardi et al., 2011). The highest rate of colonization by different Candida species occurs in patients with poor glycemic control (Javed et al., 2007).

Several predisposing risk factors have been demonstrated for oral candidiasis in diabetics such as bad oral hygiene, presence of oral dentures, age, smoking, xerostomia, and poor glycemic control (Edward, 2011 and Shrimali et al., 2011). Denture wearers comprise a population commonly described as carrier of fungal species, especially $C$. albicans because of the ability of these pathogens to adhere and form biofilm on denture-fitting surfaces, which become a reservoir of infections (Gasparoto et al., 2009). In addition, advances in life expectancy have caused broad interest in factors involved with well-being and health of the elderly people (Caruso et al., 2009).

Commensal Candida spp. inhabit different sites of the oral cavity. However, given the immunosuppressive condition in DM, these yeasts can become more virulent and express pathogenicity. They have different virulence factors, including mechanisms of cell adhesion and invasion associated with the production of enzymes especially proteinase and phospholipase that aid in tissue degradation and facilitate their proliferation in the oral mucosa (Sardi et al., 2010).

There are several antifungal medicines which can be used topically or systemically in the treatment of oral candidiasis polyenes which open channels in the fungal membrane, azoles_which inhibits cellular membrane formation by interfering with ergosterol synthesis, 5-fluorocytosine whose entry to cell is mediated by the cytosine permease. Incorporation of 5-fluorouracil into RNA interrupts protein synthesis leading to cell death (Casalinuovo et al., 2004).

The objectives of this study were to determine the prevalence of Candida infection in the oral cavity of diabetic patients, investigate the effects of age and denture wearing and other predisposing risk factors on the isolation rate of different Candida spp., to find out other risk factors 
that predispose oral candidiasis, determine some virulence factors of Candida isolates, and their susceptibility to antifungal agents.

\section{Methods and Materials}

\subsection{Patients and controls:}

The study was carried out at General Department of Internal Medicine at Al-ZahraaUniversity Hospital, Egypt between June 2013 to August 2014, included 60 adult patients with type 2 diabetes mellitus (T-2DM) suspected to have oral candidaisis. Patients diagnosed based on blood glucose level and clinical examination, and under metabolic control in the form of insulin therapy, age ranged from 30 to 85 years, have signs and symptoms in the oral cavity suggestive of Candida infection such as discrete, confluent white plaques on the buccal mucosa, tongue, and sometimes the palate, gingival, and floor of the mouth or wipeable plaques, presence of at least two of erythema, warmth, tenderness or swelling (Din et al., 2006). Predisposing factors for Candida infection such as maxillary denture wearing, periodontal diseases or other oral pathologies, gingival bleeding were reported. Patients who were on antibiotic, antifungal or corticosteroid therapy during the previous 4 weeks or patients have infections elsewhere in body were excluded from the study. Alcoholism, tobacco use, cancer, symptoms that could indicate systemic diseases, immunodeficiency, cardiovascular complication, neuropathy and pregnancy were also excluded .Complete medical and dental histories were recorded.

According to denture wearing, patients were divided into group I(a), included 19 patients with denture wearing; 7 males and 12 females, their age ranged from 47 to 79 years and group I(b), included 41 non denture wearing patients; 12 males and 29 females; their age ranged from 35 to 86 years. According to their ages patients were divided into: a) middle-aged (40-60) years and b) elder age $(>60)$ years.

All the patients signed an informed consent form to participate in the study, which was approved by the local Ethics Committee. In addition, the study included 20 healthy control subjects (group III); 6 males and 14 females their age ranged from 30 to 58 years. Patients and controls were examined for signs and symptoms of oral candidiasis.

\subsection{Samples}

Oral specimens were collected in the morning from the tongue, angle of the mouth, and buccal mucosa of patients with oral candidiasis. The samples were collected by sterile swabs, which 
were rubbed on the lesions. Material was collected from underneath the denture (hard palate) and from the denture fitting surface.

\subsection{Microbiological study}

Cultures and identification: Oral swab samples were grown on Sabouraud's Dextrose (SD) agar (Oxoid, UK) with $1 \%$ chloramphenicol and incubated at $37^{\circ} \mathrm{C}$ for $48 \mathrm{hr}$. The obtained growth was described as mild (below 10 colonies), moderate (between 11 and 50 colonies) or heavy growth (over 50 colonies) (Lamey et al., 1988). All the isolates were stored in vial tubes containing SD broth plus $10 \%$ glycerol in a $-80^{\circ} \mathrm{C}$.freezer.

Identification was done by Gram stain, subculture on SD agar for purity, followed by inoculation on CHROMagar Candida, (BioRad France). Plates were incubated for $48 \mathrm{hr}$ at $37^{\circ} \mathrm{C}$. Pink to purple colored colonies indicates $C$. albicans, intense turquoise mat convex colonies indicates $C$. tropicalis, pale turquoise colored colonies with flat, shiny, smooth morphology (fish eye) indicates $C$. glabrata and turquoise-blue colonies with rough irregular outline indicates for $C$. krusei. Microscopic features of slide culture on Cornmeal-Tween 80 agar (Oxoid, UK) and germ tube formation test were done to confirm the identification of Candida species (Kurtzman and Fell, 1998).

\section{Biochemical identification and Antifungal susceptibility studies}

Integral system yeasts Plus Candida species (Liofilchem, Italy) was used for biochemical identification and antifungal susceptibility of the isolates according to the manufacrurer in structions.

\section{Minmum inhibitory concentration (MIC) :}

E-test was done for determination of minmum inhibitory concentration (MIC) (Pfaller et al., 2002). Candida species strains were analyzed with regard to their susceptibility to 7 antifungal agents based on the minimal inhibitory concentration (MIC) in the Etest (bioMérieux SA). The following drugs and their respective minimum and maximum concentrations were used: caspofungin (CS) (concentration range, 0.002 to $32 \mu \mathrm{g} / \mathrm{mL}$ ), amphotericin B (AP) $(0.002$ to $32 \mu \mathrm{g} / \mathrm{mL}$ ), itraconazole (IT) (0.002 to $32 \mu \mathrm{g} / \mathrm{mL}$ ), and fluconazole (FLU) (0.002 to $64 \mu \mathrm{g} / \mathrm{mL}$ ).

The MICs were read as the lowest concentration at which the border of the elliptical inhibition zone of growth intercepted the scale on the Etest strip. For the MIC values that yielded results falling in between conventional serial 2-fold dilution, the next highest dilution was assigned (Motta et al., 2010). 


\section{Detection of virulence factors of Candida isolates}

The following virulence factors of different Candida spp. were studied: Germ-tube test using fetal bovine serum (Gatica et al., 2002), gelatinase production using SDA plates containing 1\% gelatin (Ramesh et al., 2011), phospholipase activity test using egg yolk agar (Samaranayake et al., 1984), and Biofilm formation by the tube adherence method (Shin et al. 2002).

\section{Statistical analysis}

Data were analyzed by Microsoft Office 2003 (excel) and Statistical Package for Social Science (SPSS) version 16. Parametric data were expressed as mean \pm standard deviation and non parametric data were expressed as number and percentage of the total. Determining the extent that a single observed series of proportions differ from a theoretical or expected distribution was done using the Chi-square test. $P$ values were insignificant when $>0.05$, significant when $<0.05$, highly significant when $<0.01$ and Marked significant when $P<0.001$ (Sokal and Rohlf, 1995).

\section{Results}

\section{Prevalence of oral candidiasis and Predisposing factors:}

Out of the 60 diabetic patients, $19(31.7 \%)$ of them were denture wearers and $41(68.3)$ of them non denture wearers. 40 patients had culture proven oral candidiasis. A significant difference was found between patients with (67\%) and without (33\%) oral candidiasis. Prevalence of candidiasis among denture wearers was (18/19) 94.7\% while in non denture wearers was (22/41) $53.7 \%$.

The most prominent predisposing factors among diabetic patients with oral candidiasis were old age, female gender, duration of diabetes $(p<0.01)$. Other predisposing factors for oral candidiasis of diabetic patients are inadequate oral hygiene (97.5\%), absence of teeth (92.5\%), caries (52.5\%), removable dentures (45\%), filled teeth (17.5\%), hypertension (97.5\%), and smoking (27.5\%).

\section{Frequency of oral candidiasis in relation to age, sex and dentur wearing (Figure 1):}

Among the 40 pateints, the frequency oral candidiasis in middle aged (40-60 years) patients was more significant (65\%) than old aged patients $(35 \%),(p<0.01)$ and in females $(65 \%)$ than males $(35 \%)(p<0.01)$. However insignificant difference $(p>0.05)$ was detected between denture wearers (45\%) and non denture wearers (55\%) among diabetics with oral candidiasis. 


\section{Candida load and Frequency of different Candida Species}

Candida load in diabetic patients was higher (92.8\%) in elder age patients than middle aged patients $77 \%$, among females $84.6 \%$ than males $50 \%$ and more prevalent $77.8 \%$ in denture wearers than non denture wearers $54.5 \%$ with significant differences $(P<0.01)$.

Sixty isolates of different Candida spp. were identified: 32 (53.3\%) C. albicans which is the most common species followed by C. glabrata 19 (31.7\%), C.tropicalis 6 (10\%) then C. krusei 3 (5\%). 52.5\% of patients have single Candida species and $47.5 \%$ of patients have multiple Candida species.

\section{Frequency of different Candida species in relation to denture}

Out of the 60 isolates, 35 (58.3\%) of them were isolated from denture weaerer patrients and $25(41.7 \%)$ were isolated from non denture weaerers with insignificant difference between them ( $P>0.05)$. Among denture wearers the frequency of $C$. albicans was $94.4 \%, C$. glabrata $66.7 \%, C$. tropicalis $22.2 \%$ and C. krusei $11.1 \%$ versus $68.2 \%, 31.8 \%, 9 \%, 5 \%$ and $4.5 \%$ in non-denture wearing respectively $(\mathrm{P}<0.01)$ except for $C$. krusei, (Figure 2$)$. .

\section{Frequency of different Candida species in relation to age}

The frequency of $C$. albicans was $80.7 \%$ and $78.6 \%$ in middle age and elder patients respectively with insignificant difference while significant higher frequency were observed in old age than middle age patients regarding C. glabrata (38.4\% versus $64.4 \%)$, C. tropicalis $(3.8 \%$ versus $35.7 \%$ ) and C. krusei (3.8\% versus14.3\%), (Figure 3).

\section{Antifungal susceptibility of the isolated Candida species}

Among the C. albicans isolates (28.1\%), were resistant to ketoconazole, (12.5\%) to voriconazole, $(9.4 \%)$ to flucytosine, $(9.4 \%)$ to fluconazole and $(3.1 \%)$ to itraconazole. While $(93.3 \%)$, (47.3\%), (36.8\%) and (5.2\%) of C. glabrata isolates were resistant to itraconazole, fluconazole, ketoconazole, voriconazole and flucytosine respectively. Among C. Tropicalis isolates; (83.3\%), (66.6\%), (50\%), (33.3\%) were resistant to fluconazole, ketoconazole, itraconazole and voriconazole respectively. The only one (33.3\%) C.krusei isolate was resistant to fluconazole, voriconazole and itraconazole. Beside, amphotercin B was very effective against all Candida isolates. Generally high rate of resistance were observed with itraconazole, fluconazole, voriconazle (Table 1).

\section{The minimal inhibitory concentration (MIC) of antifungals:}

The MICs of ketoconazle as the lowest concentration of antifungal that inhibited $100 \%$ of $C$. krusei while MIC for flucytosine that inhibited $90.6 \%$ and $84.2 \%$ of C. albicans and C. glabrata 
respectively. Also the MIC for itraconazole and voriconazole that inhibited $93.5 \%$ and $81.2 \%$ of $C$. albicans. The MIC of amphotericin B was defined as the lowest drug concentration causing $100 \%$ inhibition of all Candida species (Table 2).

\section{Virulence factors of Candida species}

Out of 60 Candida isolates, 55\% were positive for GT formation, $61.7 \%$ were positive for gelatinase activity, 58.3\% were positive for PL activity, $71.7 \%$ were positive for biofilm formation. Most of C. albicans were positive for all virulence factors. C. tropicalis were also positive for all virulence factors but less frequent than C. albicans. While $31.6 \%$ of C. glabrata and $100 \%$ C. krusei isolates were positive only for biofilm formation (Table 3).

Among denture wearers 54.5\%, 58.1\%, 51.4\%, 56.8\% were positive for germ tube formation, biofilm formation, phospholipase activity, gelatinase activity respectively versus $45.5 \%, 41.9 \%$, $48.6 \%, 43.2 \%$ in non denture wearers. Significant higher frquency $(P<0.05)$ of all virulence factors were detected among denture wearers compared to non denture wearers except for PL activity, Figure 4.

Among middle age patients $63.6 \%, 55.8 \%, 60 \%$ and $59.5 \%$ of Candida spp. were positively for germ tube, biofilm formation, phospholipase activity and gelatinase activity versus $36.4 \%, 44.2 \%$, $40 \%$ and $40.5 \%$ in elder age respectively. Significant differences $(P<0.05)$ between middle and elder ages were found in all virulence factors except biofilm formation $(P>0.05)$, Figure 5.

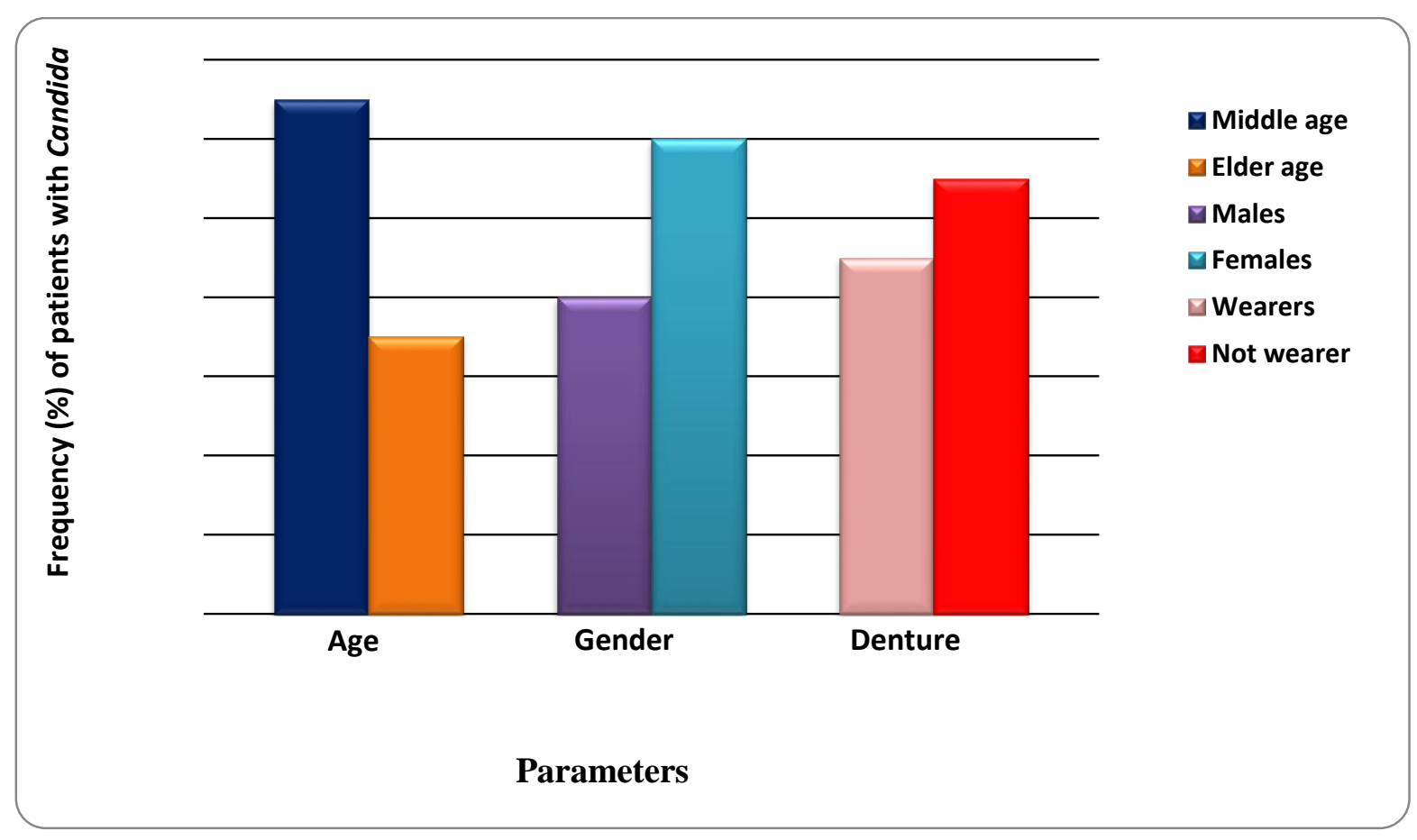

N.B: $18 / 19(94.7 \%)$ of denture wearers have candidiasis, while $22 / 41(53.6 \%)$ of non denture wearers have candidiasis with a significant difference between both. 
Figure (1): Frequency of Candida in the oral cavity in relation to age, sex, and denture wearing in diabetics with oral candidiasis.

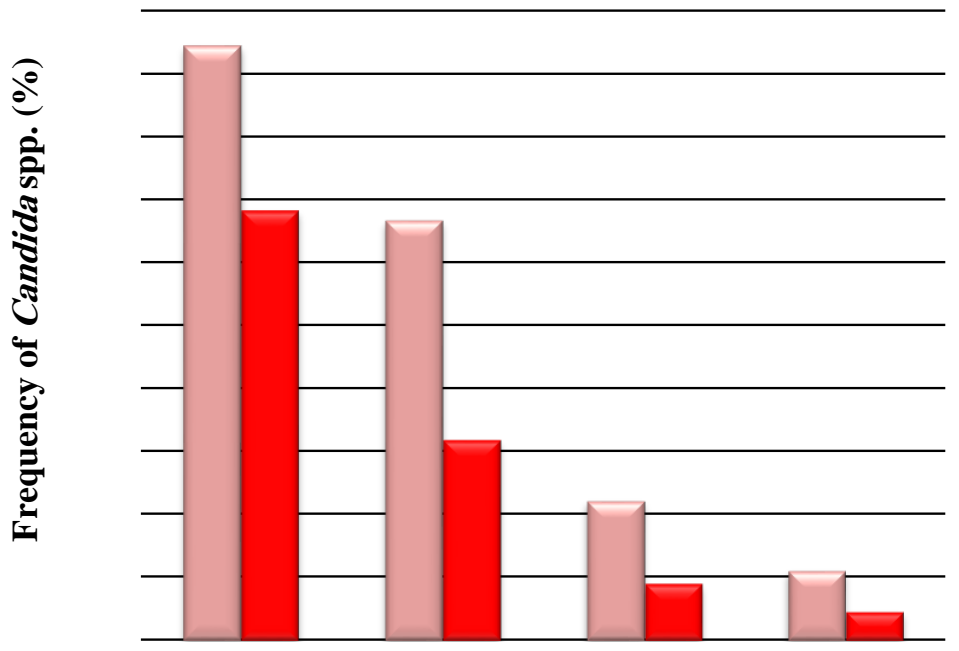

$\square$ Denture Wearer

a Non Denture Wearer

\section{Candida species}

* 35 (58.3\%) of Candida species isolated from denture weaerer patrients and 25 (41.7\%) of Candida species isolated from non denture weaerer patients.

Figure(2): Distribution of Candida spp. in relation to denture wearing.

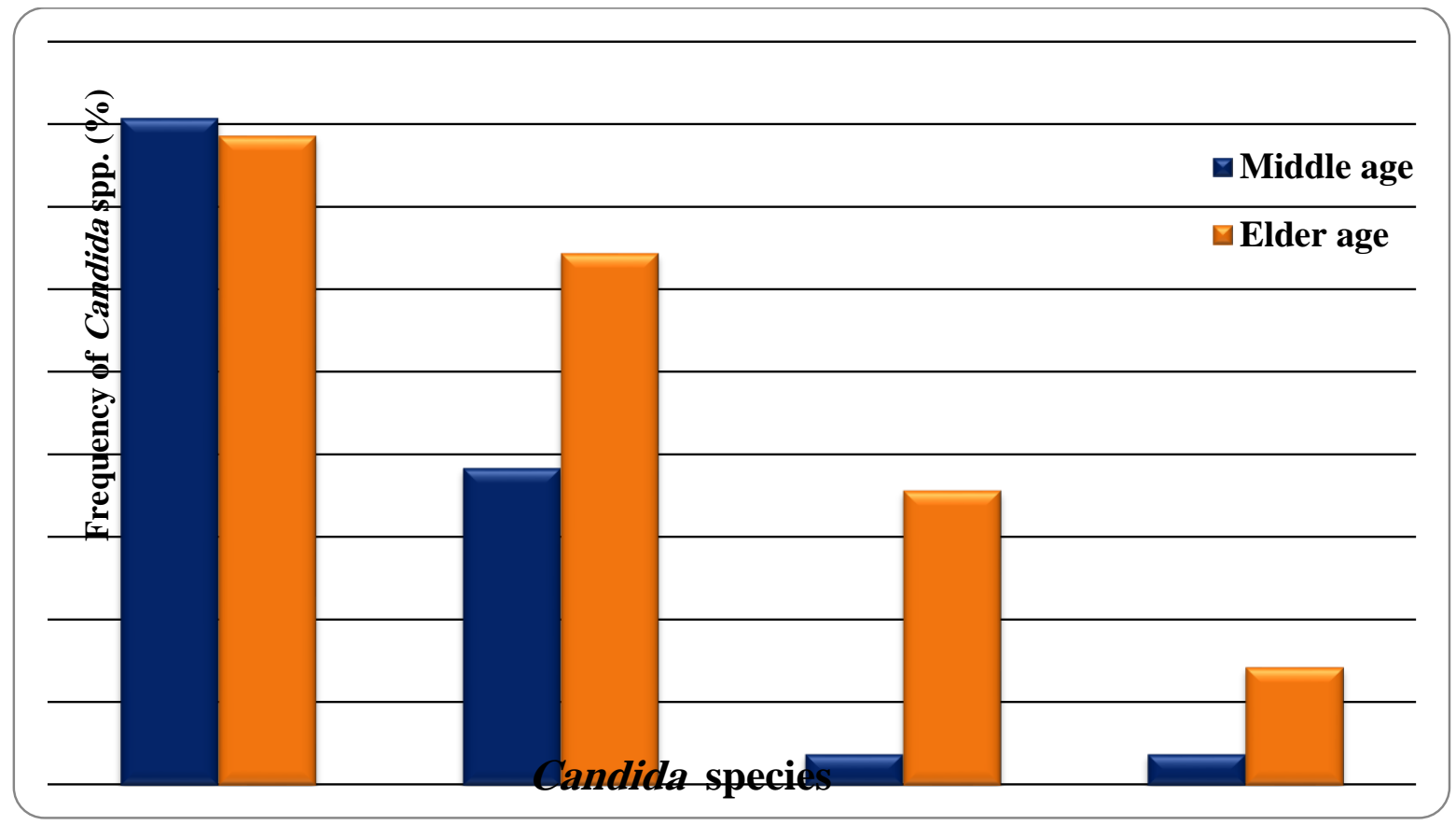

* 33 (55\%) of Candida species isolated from middle age patients and 27 (45\%) of Candida species isolated from elder age patients.

Figure (3): Distribution of Candida spp in relation to age. 
Table (1): The antibiogram patterns of Candida species using integral yeast plus system.

\begin{tabular}{|c|c|c|c|c|c|c|c|c|c|c|c|c|}
\hline \multirow{3}{*}{$\begin{array}{l}\text { Antifungl } \\
\text { agent }\end{array}$} & \multicolumn{3}{|c|}{ Condidn albiouns ( $(\mathrm{u}=32)$} & \multicolumn{3}{|c|}{ Condido glabrua $(\mathrm{n}=19)$} & \multicolumn{3}{|c|}{ Condidu topicalis $(\mathrm{l}=6)$} & \multicolumn{3}{|c|}{ Condida huxi(n=3) } \\
\hline & $\mathrm{R}$ & $\$$ & DDS & $\mathbf{R}$ & $S$ & DDS & $\mathbb{R}$ & $S$ & DDS & $\mathbf{R}$ & $s$ & DDS \\
\hline & $N \%$ & $\mathrm{~N} \%$ & $\$ 8$ & $N \%$ & $N \%$ & $\mathrm{~N} \%$ & $\$ \%$ & $\$ \%$ & $\$ \%$ & $\mathrm{~N} \%$ & $N \%$ & $\mathrm{~N} \%$ \\
\hline$A \mathbb{A}$ & $\cdot \cdot$ & 32100 & $\cdot \cdot$ & $\cdot$ & 19100 & $\cdot \cdot$ & . & 6100 & . & $\cdot \cdot$ & 3100 &. \\
\hline $\mathrm{FCl}$ & 39.4 & 2990.6 & $\cdot \cdot$ & 15.2 & 1684.2 & 210.5 & - & 583.3 & 116.6 & - - & 266.7 & 133.3 \\
\hline $\mathrm{KET}$ & 928.1 & 216.6 & 262 & 7368 & 947.3 & 315.7 & 466.6 & 116.6 & 116.6 & $\cdot-$ & 3100 & . \\
\hline ITR & 13.1 & 3093.5 & 131 & 1893.3 & - & 15.2 & 35 & 233.3 & 116.6 & 133.3 & 266.7 & - \\
\hline $\mathrm{TOR}$ & 412.5 & 2681.2 & 262 & 7368 & 1157.8 & 210.5 & 233.3 & & 466.6 & 133.3 & 266.7 & - \\
\hline$\overline{\mathrm{FL}}$ & 39.4 & 2165.6 & 825 & $\begin{array}{|ll|}9 & 47.3 \\
\end{array}$ & 210.5 & 1157.9 & 583.3 & 116.6 &. & 133.3 & 266.7 &. \\
\hline
\end{tabular}

AMB Amphotericin $2 \mu \mathrm{g} / \mathrm{mL}$; FCY Flucytosine $16 \mu \mathrm{g} / \mathrm{mL}$; KCA Ketoconazole $0.5 \mu \mathrm{g} / \mathrm{mL}$; ITR Itraconazole $1 \mu \mathrm{g} / \mathrm{mL}$; VOR Voriconazole 2 $\mu \mathrm{g} / \mathrm{mL}$; FLU Fluconazole $64 \mu \mathrm{g} / \mathrm{ml}$. R; resistant, DDS; dose dependent sensitive and S; sensitive

Table(2): Mean MIC values for the isolated Candida species.

\begin{tabular}{|c|c|c|c|c|c|c|}
\hline \multirow[b]{2}{*}{ Antifungal agent } & \multirow[b]{2}{*}{ Code } & \multirow[b]{2}{*}{$\begin{array}{l}\text { Conc } \\
(\mu \mathrm{g} / \mathrm{ml})\end{array}$} & \multicolumn{4}{|c|}{ Breakpoint } \\
\hline & & & $\begin{array}{l}\text { C. albicans } \\
\mathrm{N}=32\end{array}$ & $\begin{array}{l}\text { C. glabrata } \\
\mathrm{N}=19\end{array}$ & $\begin{array}{l}\text { C. tropicals } \\
\mathrm{N}=6\end{array}$ & $\begin{array}{l}\text { C. krusei } \\
\mathrm{N}=3\end{array}$ \\
\hline Amphotericin & AMB & $\begin{array}{l}0.002- \\
32\end{array}$ & 0.315 & 0.157 & 0.625 & 0.625 \\
\hline Flucytosine & FCY & $\begin{array}{l}0.002- \\
32\end{array}$ & 0.014 & 1.25 & 0.014 & 2.5 \\
\hline Ketoconazole & KET & $\begin{array}{l}0.002- \\
32\end{array}$ & 0.014 & 0.014 & 0.109 & 0.625 \\
\hline Itraconazole & ITR & $\begin{array}{l}0.002- \\
32\end{array}$ & 0.024 & 0.22 & 0.027 & 0.875 \\
\hline Voriconazole & VOR & $\begin{array}{l}0.002- \\
32\end{array}$ & 0.014 & 0.027 & 0.345 & 0.21 \\
\hline Fluconazole & FLU & $\begin{array}{l}0.002- \\
64\end{array}$ & 0.22 & 0.44 & 1.75 & 14 \\
\hline Capsofungin & CAS & $\begin{array}{l}0.002- \\
32\end{array}$ & 0.157 & 0.22 & 0.44 & 0.625 \\
\hline
\end{tabular}


Table (3): Distribution of virulence factors among Candida species

\begin{tabular}{|c|c|c|c|c|c|c|c|c|c|c|}
\hline \multirow[t]{3}{*}{ Virulence factor } & \multirow{2}{*}{\multicolumn{2}{|c|}{$\begin{array}{l}\text { Positive } \\
\text { isolates }\end{array}$}} & \multicolumn{8}{|c|}{$\begin{array}{l}\text { Candida species } \\
\qquad \begin{array}{l}\mathrm{N}=60 \\
\end{array}\end{array}$} \\
\hline & & & \multicolumn{2}{|c|}{$\begin{array}{l}\text { C.albicans } \\
N=32\end{array}$} & \multicolumn{2}{|c|}{$\begin{array}{l}\text { C.glabrata } \\
\mathrm{N}=19\end{array}$} & \multicolumn{2}{|c|}{$\begin{array}{l}\text { C.tropicalis } \\
\mathrm{N}=6\end{array}$} & \multicolumn{2}{|c|}{$\begin{array}{l}\text { C. krusei } \\
\mathrm{N}=3\end{array}$} \\
\hline & No & $\%$ & No & $\%$ & No & $\%$ & No & $\%$ & No & $\%$ \\
\hline $\begin{array}{ll}\text { Germ } & \text { tube } \\
\text { ormation } & \end{array}$ & $33 / 60$ & 55 & $32 / 32$ & 100 & - & - & $1 / 6$ & 16.7 & - & - \\
\hline Biofilm formation & $43 / 60$ & 71.7 & $30 / 32$ & 93.7 & $6 / 19$ & 31.6 & $4 / 6$ & 66.7 & $3 / 3$ & 100 \\
\hline PL activity & $35 / 60$ & 58.3 & $31 / 32$ & 96.8 & - & - & $4 / 6$ & 66.7 & - & - \\
\hline Gelatinase activity & $37 / 60$ & 61.7 & $32 / 32$ & 100 & - & - & $5 / 6$ & 83.3 & - & - \\
\hline
\end{tabular}

* $21 / 40$ (52.5\%) of patients have single Candida species and $19 / 40$ (47.5\%) of patients have multiple Candida species.

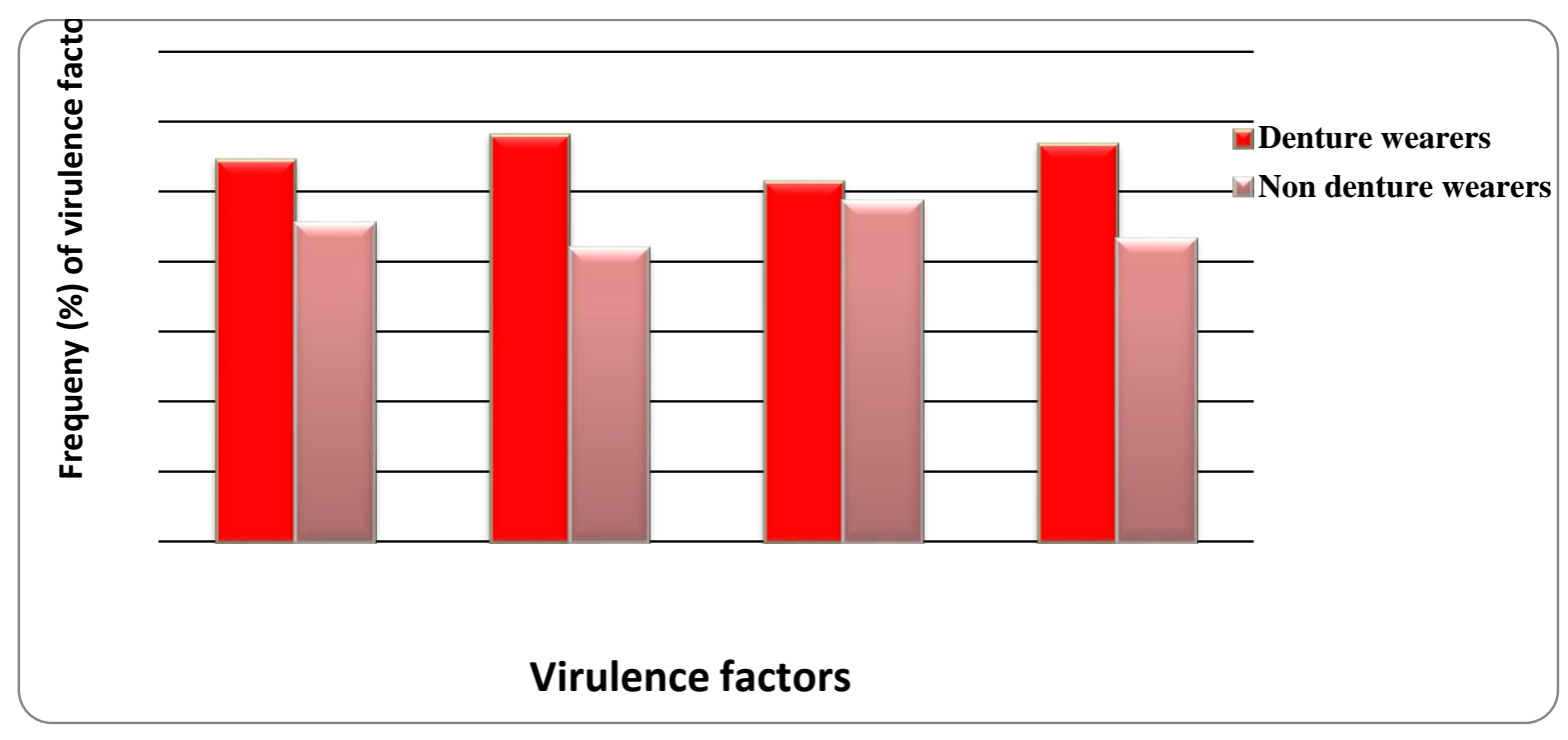

Figure (4): Relationship between virulence factors of Candida species and denture wearing. 


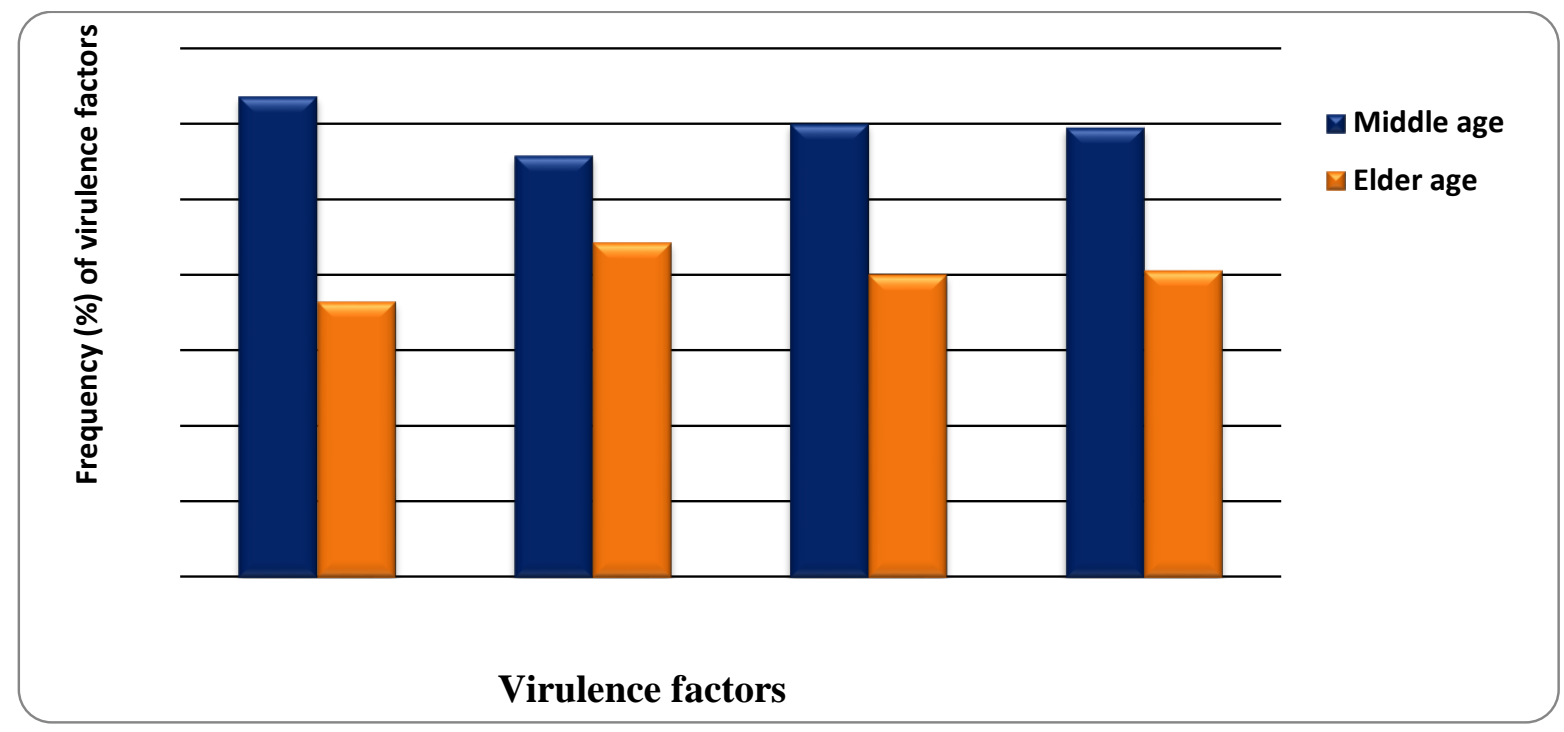

Figure (5): Relationship between virulence factors of Candida species and patient's ages

\subsection{Discussion}

The objectives of this study were to determine the prevalence of Candida infection in the oral cavity of diabetic patients, investigate the effects of age and denture wearing and other predisposing risk factors on the isolation rate of different Candida spp., determine some virulence factors of Candida isolates, and in vitro their susceptibility to antifungal agents,

In the present study the prevalence of Candida infection in the oral cavity of diabetic patients was 67\%. This finding is in accordance with that of Soysa et al., (2006) who reported that the presence of Candida spp. in the oral mucosa in diabetic patients, reached up to $80 \%$. In addition our finding is similar to that of Sardi et al. (2013) and Belazi (2005), who studied 128 diabetic and 84 non diabetic patients, Candida was isolated from the oral cavity of $64 \%$ of the diabetic patients. Incontrast, Carlos et al. (2013) found that only $25 \%$ had a positive result. Tsang et al., (2007) found also that C. albicans was isolated from $36.2 \%$ of patients with DM. Oral candidiasis is explained by the significant association with the glycemic control and changes in salivary $\mathrm{pH}$ due to hyperglycemia (Kumar and Kannan, 2010).

Slight alterations the physiological condition of the host in can turn a harmless commensal microorganism into a pathogen. The transition is attributable to the suitable predisposing conditions that occur in the host (Bhat et al., 2011). The current study revealed that the most common predisposing factors in the oral cavity were inadequent oral hygiene $(97.5 \%)$, absence of teeth (92.5\%), caries $(52.5 \%)$, and denture wearing $(45 \%)$. long duration of diabetes $>10$ years $(77.5 \%)$, female sex (60\%) and the middle aged (40-60 years) patients (65\%). In addition, Candida load in 
diabetic patients was higher (92.8\%) in elder age patients than middle aged patients $77 \%$, among females $84.6 \%$ than males $50 \%$ and more prevalent $77.8 \%$ in denture wearers than non denture wearers $54.5 \%$ with significant differences.

Frequent oral candidiasis occurs in $45 \%$ of denture wearers in this study. However, Lakshmipriya et al., (2014) found that the prevalence of Candida spp. was (93\% vs 53\%) in denture wearers and non-denture wearers diabetics and explained that candidal colonization in the oral cavity of denture wearing increases and its growth rate was found higher in diabetic denture wearers due to their immune-compromised status. Denture wearing is supportive of growth of species as $C$. albicans, C. tropicalis, and C. glabrata (Hiroyuki et al., 2007). Similarly, Lakshmipriya et al. (2014) and Lotfi-Kamran et al. (2009) reported that prevalence of Candida in diabetic was $93 \%$ in denture wearers and $53 \%$ in non denture wearers.

Aging has been believed to cause progressive increases of Candida in the oral cavity. Our results indicated that the incidence of Candida spp. in middle aged patients was higher (65\%) than elderly subjects (35\%). In contrast, Zaremba et al. (2006) that found no significant difference between middle aged subjects (67.3\%) and the elderly (58.8\%). Lakshmipriya et al. (2014) reported also an equivalent rate between middle age (40-60) years old and elder age (>60years) old. However, Resende Pinho (2002) reported that the isolation rates of Candida species to be high in ages ranging from $60-80$ years.

A higher percentage of female patients was observed in the present investigation, and this result agrees with previous studies (de Resende et al., 2006). Espinoza et al. (2003) who found that elderly women presented more oral lesions than men and that the hormonal factor and the great incidence of iron deficiency in women could be responsible for that disparity (Figueiral et al., 2007).

Sixty isolates of different Candida Spp. were identified: $53.3 \%$ C. albicans which is the most common species followed by C. glabrata $31.7 \%$, C.tropicalis $10 \%$ then C. krusei $5 \%$. $52.5 \%$ of patients have single Candida species and $47.5 \%$ of patients have multiple Candida species. The most commonly isolated species was $C$. albicans. The present study supported the hypothesis that, although, $C$. albicans was the most common species isolated from patients with candidiasis; yet the Candida non albicans (CNA) species were found to be emerging (Daniluk et al. 2006), where it was determined that $43.8 \%$ of diabetic patients had C. albicans. In agreement with findings of others (Back-Brito et al., 2009), the majority of yeast isolates from oral cavity were C.albicans, but it was often recovered in association with other yeasts. These results are in accordance with Manikandan and Amsath, (2013), they reported that C. albicans was found to be the predominant with $70 \%$ followed by C. glabrata $16.6 \%$, C.krusei and C. tropicalis $6.7 \%$ for each. Moreover, a study conducted 
by Raju and Shashanka, (2012), has reported a similar pattern of distribution of species and explained that the more or less similarity with these studies could be due to variation in geographical distribution of various Candida species.

Frequent occurrence of multiple Candida species sets denture wearers apart from subjects who do not wear dentures. Denture wearing is supportive of growth of species as $C$. albicans, $C$. tropicalis, and C. glabrata (Hiroyuki et al., 2007).

The findings that most of C.albicans have high rates of resistance to itraconazole and all Candida Non Albicans species have high rates of resistance to itraconazole, flucytosine and fluconazole. Sachin (2014) reported that $C$. tropicalis isolates were found to be more resistant to fluconazole. Resistance to fluconazole and itraconazole was observed relatively high, mainly in isolates of C. glabrata, C. tropicalis and C. albicans (Bruder- Nascimento et al., 2010) while Baysan et al. (2012) revealed that $C$. krusei is intrinsically resistant to fluconazole. High secondary resistance rates were observed in C. glabrata to fluconazole (68\%) and itraconazole (88\%); this resistance to multiple azoles has been explained by an upreglutation of CDR genes that encode the CDR efflux pumps (Pfaller and Diekema, 2007). Candida glabrata strain resistant to itraconazole was recovered in Brazilian tertiary care hospital and similar results with C. krusei and C. tropicalis isolates were reported in Greece (Behiry et al., 2010).

The findings that all 60 Candida isolates were susceptible to amphotericin $\mathrm{B}$, are similar to reports of Behiry et al. (2010) who found that all 40 Candida isolates were susceptible to amphotericin B. Moreover, $81.2 \%$ of C. albicans, $57.8 \%$ of C. glabrata, $50 \%$ of C. tropicalis and $66.7 \%$ of $C$. krusei in this study were susceptible to voriconazole with similar result reported by Baysan et al. (2012) who found that all Candida species were susceptible to voriconazole except one $C$. glabrata strain which was intermediate susceptible.

The current work revealed that most of $C$. albicans were positive for all virulence factors. $C$. tropicalis were also positive for all virulence factors but less frequent than C. albicans. While $31.6 \%$ of C. glabrata and $100 \%$ C. krusei isolates were positive only for biofilm formation. Significant higher frquency of all virulence factors were detected among denture wearers compared to non denture wearers except for PL activity. The study of Barros et al., (2008) revealed that 30 to $100 \%$ of the oral isolates of $C$. albicans produce phospholipases with variable degrees of enzymatic activity Similarly, Sardi et al. (2013) reported that phospholipase activity was detected in $95.5 \%$ and proteinase activity in $100 \%$ of C. albicans isolates and Tsang et al. (2007) also found a high proteinase activity in type 2 DM patients. Manfredi et al. (2006) reported that proteinase expression is not significantly higher in Candida isolates from patients with diabetes when compared to healthy patients and that 
type 2 DM patients have higher proteinase levels than type 1 DM patients. Deorukhkar and Saini, (2014) reported that maximum phospholipase activity was seen in C. albicans (81.6\%) and among NAC spp. maximum phospholipase activity was noted in C. tropicalis and C. glabrata. Interstingly, Candida cells in a biofilm exhibit a significant resistance to several antimicrobial drugs, notably the popular azole drugs (Maia et al., 2008). High rates of biofilm formation of Candida spp. were detected in this study. These results are in agreement with Yigit et al. (2011), who found that biofilm production in Candida strains isolated from denture stomatitis, were $88.2 \%$ of C. albicans strains were biofilm producers, while $60 \%$ of C. glabrata, $44.4 \%$ of C. krusei, $57.1 \%$ of $C$. kefyr and $40 \%$ of $C$. parapsilosis positive for biofilm production.

\section{Conclusion}

Oral Candidiasis is strongly associated with diabetes and is more common among middle aged, female gender denture wearers and it is, hence controlling serum glucose level is essential. Dentures need to be cleaned daily with effective antifungal agents but there comes a time when a denture can no longer be cleaned effectively and must be replaced. So better oral hygiene is necessitated among denture wearers.

\section{References}

Abaci, O. and Haliki-Uztan, A. Ivestigation of the susceptibility of Candida species isolated from denture wearers to different antifungal antibiotics. Afr. J. Microbiol. Res. 5(2): 1398-1403 (2011).

Back-Brito, G.N.; Mota, A.J.; Vasconcellos, T.C.; Querido, S.M.R.; Jorge, A.O.C.; Reis, A.S.M. and Balducci Cristiane, Y. Frequency of Candida spp. in the Oral Cavity of Brazilian HIV-Positive Patients and Correlation with CD4 Cell Counts and Viral. Load. Mycopathol. 167: 81-87 (2009).

Barros, L.M.; Boriollo, M.F.; Alves, A.C.; Klein, M.I.; Gonçalves, R.B. and Höfling, J.F. Genetic diversity and exoenzyme activities of Candida albicans and Candida dubliniensis isolated from the oral cavity of Brazilian periodontal patients. Arch. Oral. Biol. 53:1172-1178 (2008).

Baysan, B.O.; Ogunc, D.; Colak, D.; Ongut, G.; Donmez, L.; Vural, T. and Gunseren, F. Distribution and antifungal susceptibility of Candida species causing nosocomial candiduria. Med. Mycol. 50: 529-532 (2012). 
Behiry, I.K.; El Hedeki, S.K. and Mahfouz, M. Candida infection association with urinary catheter in critically ill patients. Identification, antifungal susceptibility and risk factors. Res. J. Med. and Med. Sci., 5(1): 79-86 (2010).

Belazi, M.; Velegraki, A.; Fleva, A.; Gidarakou, I.; Papanaum, L.; Baka, D.; Danülidou, N. and Karamitos, D. Candidal overgrowth in diabetic patients: potential predisposing. Mycoses, 48: 192-196 (2005).

Bhat, V.; Sharma, S.M.; Shetty, V.; Shastry, C.S. and Rao, V. Extracellular enzymes of candida albicans and their role in the development of denture stomatitis- a review. JIADS. (21):26-30 (2011).

Brissaud, O.; Guichoux, J.; Harambat, J.; Tandonnet, O. and Zaoutis, T. Invasive fungal disease in PICU: epidemiology and risk factors. Ann. Intensive Care 2: 6 (2002).

Bruder Nascimento, A.; Camargo, C.H.; Sugizaki, M.F.; Sadatsime, T.; Montelli, A.C. and Mondelli, A.L.E. Species distribution and susceptibility profile of Candida species in a Brazilian public tertiary hospital. B.M.C. Res. Notes. 3: 1-5 (2010).

Carlos, G.G.L.; Anakaren, G.C.; Nemesio, E.G.; Israel, M.G.G. and Patricia, G.P. Incidence of Candida albicans in diabetic patients with a dental prosthesis in Northeast Mexico. Afr. J. Microbiol. Res. 7(41): 4844-4847 (2013).

Caruso, C.; Buffa, S.; Candore, G.; Colonna-Romano, G.; Dunn-Walters, D. and Kipling, D. Mechanisms of immunosenescence. Immun. Ageing. 6:10 (2009).

Caslinuovo, I.A.; Di Franceseco, P. and Garaci, E. Fluconazole resistance in Candida albicans: a review of mechanisms. Eur. Rev. Med. Pharmacol. Sci. 8:69-77 (2004).

Daniluk, T.; Tokajuk, G.; Stokowska, W.; Fiedoruk, K.; Sciepuk, M.; Zaremba, M.L.; Rozkiewicz, D.; Cylwik-Rokicka, D.; Kedra, B.A.; Anielska, I.; Górska, M. and Kedra, B.R. Occurrence rate of oral Candida albicans in denture wearer patients. Adv. Med. Sci. 51 Suppl 1 : 77-80 (2006).

Deorukhkar,S. and Saini, S. "Virulence markers and antifungal susceptibility profile of Candida glabrata: an emerging pathogen," Br. Microbiol. Res. J. 4 (1): 35-45 (2014).

de Resende, M.A.; de Sousa, L.V.; de Oliveira, R.C.; Koga-Ito, C.Y. and Lyon, J.P. Prevalence and antifungal susceptibility of yeasts obtained from the oral cavity of elderly individuals. Mycopathologia. 162:39-44 (2006).

Din, J.U.; Qureshi, M.B.; Khan, A.J. and Khan, M.D. Prevalence of diabetic retinopathy. J Ayub Med. Coll. Abbotabad.18: 40-43 (2006). 
Edward, J.E. Candidiasis. Principles of Internal Medicine. In:Kasper D.L.;Fauci, A.S. and Longo, D. edi. Harrisons USA. Mc Graw Hill; 1254-1256 (2011).

Espinoza, I.; Rojas, R.; Aranda, W. And Gamonal,J. Prevalence of oral mucosal lesions in elderly people in Santiago, Chile. J. Oral. Pathol. Med.32:571-575 (2003).

Figueiral, M.H.; Azul, A.; Pinto, E.; Fonseca, P.A.; Branco, F.M,. and Scully, C. Denture-related stomatitis: Identification of aetiological and predisposing factors-a large cohort. J. Oral. Rehabil. 34:448-455 (2007).

Gatica, J.L.M.; Goic, I.B. and Martinez, M.A.T. Utilidad del agar chromo Candida para el diagnostico diferencial de Candida spp aisladas de muestras vaginales. Rev. Chil. Obstet. Ginecol. 67: 300304 (2002).

Gasparoto, T.H.; Vieira, N.A.; Porto, V.C.; Campanelli, A.P. and Lara, V.S. Ageing exacerbates damage of systemic and salivary neutrophils from patients presenting Candida-related denture stomatitis. Immun Ageing.; 6:3 (2009).

Germain, G.; Laverdiere, M. and Pelletier, R. Prevalence and antifungal susceptibility of 442 Candida isolates from blood and other normally sterile sites: Results of a 2-year (1996-1998) multicentre surveillance study in Quebec, Canada. J. Clin .Microbiol. 39: 949-953 (2001).

Hiroyuki, M.; Emiko, I.; Kimiharu,H. Effect of Denture Wearing on occurrence of Candida Species in the Oral Cavity. J. Appl. Res. 7(3):250-254 (2007).

Janet. H.; Southerland, G.W. and Taylor, S.O. Diabetes and periodical infection: Making the connection. Clin. Diabet. 23:171-178 (2005).

Javed, F.; Näsström, K.; Benchimol, D.; Altamash, M.; Klinge, B. and Engström, P.E. Comparison of periodontal and socioeconomic status between subjects with type 2 diabetes mellitus and nondiabetic controls. J. Periodontol. 78:2112-2119 (2007).

Kumar, R.S. and Kannan, R. Salivary glucose levels and oral Candidal carriage in type II diabetics. Oral Surg. Oral Med. Oral Pathol. Oral Radiol. Endod. 109(5): 706-711 (2010).

Kurtzman, C.P. and Fell, J.W. The yeasts: A taxonomic study, 4th ed. Elsevier Science Ltd. New York, pp. $891-947$ (1998).

Lakshmipriya, R.; Surya Prabha, P.; Divya Rani, M. and Chitralekha, S. Prevalence of Candida among Denture and Non Denture Wearers. RJPBCS. 5(2): 716-720 (2014). 
Lamey P.J.; Darwaza, A.; Fisher, B.M.; Samaranayake, L.P.; MacFarlane, T.W. and Frier, B.M. Secretor status, candidal carriage and candidal infection in patients with diabetes meilitus. J. Oral Pathol. 17: $354-357$ (1988).

Laverdiere, M.; Labbe, A.C.; Restieri, C.; Rotstein, C.; Heyland, D.; Madger, S. and Stewart, T. Susceptibility patterns of Candida species recovered from candidian intensive care units. J. Crit. Care. 22: 245-251 (2007).

Maia, L.F.; Specian, A.F.; Bizerra, F.C.; Oliveira, M.T. and Furlaneto, M.C. In vitro evaluation of putative virulence attributes of oral isolates of Candida spp. Obtained from elderly healthy individuals. Mycopathologia. 166: 209-217 (2008).

Mane, A.; Pawale, C.; Gaikwad, S.; Bembalkar, S. and Risbud, A. Adherence to buccal epithelial cells, enzymatic and hemolytic activities of Candida isolates from HIV-infected individuals. Med. Mycol. 49:548-551 (2011).

Manfredi, M.; Mc Cullough, M.J.; Al-Karawi, Z.M.; Vescori, P. and Porter, S.R. In vitro evaluation of virulence attributes of Candida spp. isolated from patients affected by diabetes mellitus. Oral. Microbiol. Immunol. 21:183-189 (2006).

Manikandan,C. and Amsath, A. Isolation and Rapid identification of Candida species from the Oral cavity. Int. J. Pure App. Biosci. 1 (3): 23-27 (2013).

Motta, A. L.; Almeida, G.M.; Almeida Júnior, J.N.; Burattini, M.N. and Ross,i F. Candidemia epidemiology and susceptibility profile in the largest Brazilian teaching hospital complex. Braz. J. Infect Dis.14:441-448 (2010).

Lotfi-Kamran,M.H.; Jafari, A. A.; Falah-Tafti, A.; Tavakoli, E. and Falahzadeh, M.H. Candida colonization on the denture of diabetic and nondiabetic patients. Dent. Res. J. 6:23-27 (2009).

Pfaller, M., Messer,S.; Hollis, R.; Jones, R. and Diekema, D. In vitro activities of ravuconazole and voriconazole compared with those of four approved systemic antifungal agents against 6,970 clinical isolates of Candida spp. Antimicrob. agents chemother.. 46:1723-1727 (2002).

Pfaller, M.A. and Diekema, D.J. Azole antifungal drug cross resistance: Mechanisms epidemiology and clinical significance. J. Invasive Fungal Infect. 1: 74-92 (2007).

Raju,B.S. and Shashanka, R. Isolation and Identification of Candida from the Oral Cavity. Int. Scholarly Res. Network ISRN Dent. 10: 5402 (2011). 
Ramesh, N.; Priyadharsini, M.; Sumathi, C.S.; Balasubramanian, V.; Hemapriya, J. and Kannan, R. Virulence factors and antifungal sensitivity pattern of Candida Sp. isolated from HIV and TB patients. Indian. J. Microbiol. 51: 273-278 (2011).

Resende Pinho, J.C.; De Resende, M.A. and Saliba, J.L. Prevalence of Candida species in hospitalized patients and their risk factors. Mycoses, 45: 306 (2002).

Sachin, C.; Deorukhkar, S. and StephenMathew. Virulence Factors Contributing to Pathogenicity of Candida tropicalis and Its Antifungal Susceptibility Profile. Int. J. Microbiol. 1-6 (2014).

Safia, A. Candida colonization, strain diversity and antifungal susceptibility among adult diabetic patients. Ann. Saudi med. J. 30(2): 101-108 (2010).

Samaranayake, L.P.; Raeside, J.M. and MacFarlane, T.W. Factors affecting the phospholipase activity of Candida species in vitro. Sabouraudia. 22: 201-207 (1984).

Santana, D.P.; Odriues, T.; Souza, S.O.; Naves, P.L.F. and Ribeiro, E.L. Prevalência de fatores de virulência de Candida albicans isoladas da cavidade bucal de crianças portadoras e não portadoras de síndrome de Down. Enciclopédia. Biosfera. 6: 1-10 (2010).

Sardi, J.C.; Duque, C.; Mariano, F.S.; Peixoto, I.T.; Höfling, J.F. and Gonçalves, R.B. Candida spp. in periodontal disease: a brief review. J. Oral Sci.52:177-185 (2010).

Sardi, J.C.; Duque, C.; Camargo, G.A.; Hofling, J.F. and Gonçalves, R.B. Periodontal conditions and prevalence of putative periodontopathogens and Candida spp. in insulin-dependent type 2 diabetic and non-diabetic patients with chronic periodontitis - A pilot study. Arch. Oral Biol. 56:1098-1105 (2011).

Sardi, J.C.O.; Vilas-Boas, P.; Aguiar, N.; Fonseca, M.; Theobaldo, J. and Höfling, J.F. In vitro Evaluation of Phospholipase and Proteinase of Candida albicans Isolated From Oral Cavity of Diabetic Patients; 15 (1):9-12 (2013).

Shin, J.H.; Kee, S.H.; Shin, M.G.; Kim, S.H.; Shin, D.H.; Lee, S.K.; Suh, S.P. and Ryang, D.W. Biofilm production by isolates of Candida species recovered from non neutropenic patients: Comparison of bloodstream isolates with isolates from other sources. J. Clin. Microbiol. 40: 12441248 (2002).

Shrimali, L.; Astekar, M. and Sowmya, G.V. (2011). Correlation of oral manifestations in controlled and uncontrolled diabetes mellitus. Int. J.Oral \& Maxillofacial Pathol. 2(4): 24-27. 
Sokal, R.R. and Rohlf, F.J. Biometry: The principles and practice of statistics in biological research. $2^{\text {nd }}$ edn. W.H. Freeman, New York (1995).

Soysa, N.S.; Samaranayake, L.P. and Ellepola, AN. Diabetes mellitus as a contributory factor in oral candidosis. Diabet. Med. 23:455-459 (2006).

Tsang, C.S.; Chu, F.C.; Leung, W.K.; Jin, L.J.; Samaranayake, L.P and Siu, S.C. Phospholipase, proteinase and haemolytic activities of Candida albicans isolated from oral cavities of patients with type 2 diabetes mellitus. J. Med. Microbiol. 56:1393-1398 (2007).

Wild, S.; Roglic, C.; Gran, A. global prevalence of diabetes: Estimates for the year 2000 and projections for 2030. Diabet. Care. 27: 1047-1053 (2004).

Yigit, N.; Aktas, E.; Dagistan, S. and Ayyildiz, A. "Investigating biofilm production, coagulase and hemolytic activity in Candida species isolated from denture stomatitis patients," Eur. J. Med. 43(11): 27-32 (2011).

Zaremba, M.L.; Daniluk, T.; Rokiewicz, D.; Cylwik-Rokicka, D.; Kierklo, A.; Tokajuk, G.; Dąbrowska, E.; Pawińska, M.; Klimiuk, A.; Stokowska, W. and Abdelrazek, S. Incidence rate of Candida species in the oral cavity of middle-aged and elderly subjects. Adv. Med. Sci. 51(1): 233-236 (2006). 


\section{الملخص العربى}

معدل تواجد أنواع الكانديدا فى تجويف الفم ومخاطرها لمرضى السكرى

إلهام السيد مصطفى' ،زينب محمد خيرالل' ، سهير سعيد مقلد ، منى عبدالرؤف' ، سناء محمد عاثور'

' كلية البنات للآداب و العلوم و التربية ـجامعة عين شمس ـ القاهرة - مصر

$$
\text { بكلية الطب-جامعة الأزهر (بنات) - القاهرة- مصر }
$$

تمثلت أهداف هذه الدراسة فى معرفة مدى انتشار الإصابة بفطر الكانديدا فى التجويف الفمى لمرضى السكرى

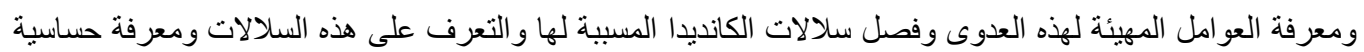

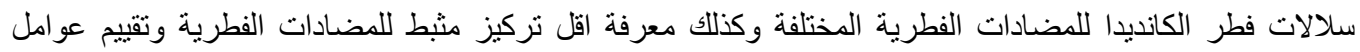
الضراوة للفطر مثل تكوين أنبوبة الإنبات وتكوين الفيلم الحيوى و إفراز إنزيمات الفسفوليبيز والجيلاتينيز.

وشملت الدراسة . T من مرضى السكرى يشتبه فى وجود عدوى التجويف الفمى بفطر الكانديدا لديهم وبعد عمل

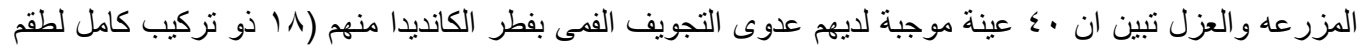

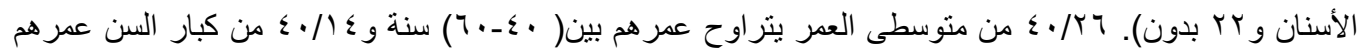

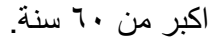

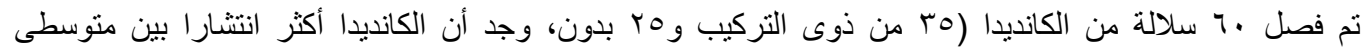
العمرو الإناث بنسبة 70\% لكل وكان معدل فصل السلالات من العينات الموجبة كالاتى: كانديدا البيكانز ؟ب. به\% يليها

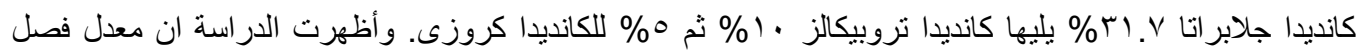

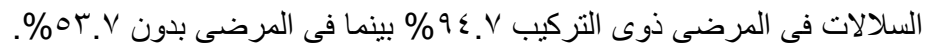

وقد أظهرت الدراسة أن أقل تركيز للكيتوكونازول مثبط ل . . 1\% من الكانديدا كروزى بينما اقل تركيز للفلوسيتوزين مثبط لج. •9\% و ץ.^^\% من الكانديدا البيكانز والكانديدا جلابراتا على التوالى وايضا اقل تركيز للايتراكونازول و الفوريكونازول مثبطة له. ب9\% و r. 1)\% للكانديدا البيكانزلكل. وتبين من الدراسة ان الكانديدا البيكانز والكانديدا جلابراتا قادرنان على تكوين انبوبة انبات وتكوين الفيلم الحيوى و انتاج

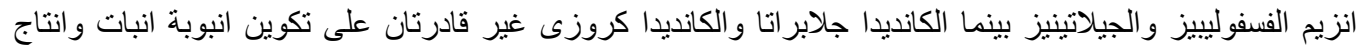
انزيم الفسفوليييز و الجيلاتينز ولكن الكانيدا كروزى لها القدرة على تكوين الفيلم الحيوى.

وتبين من الدراسة ان الكانيدا البيكانز من اكثر الأنو اع انتشارا وشيوعا فى التجويف الفمى لمرضى السكرى حيث أن لها

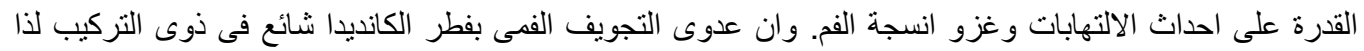
لابد من التحكم فى مستوى السكر فى سيرم الدم و يساهم عدم تنظيف التركيب فى الاصابة بالفطريات التى ترنبط

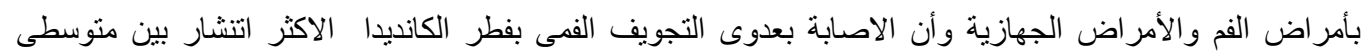

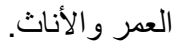

